\title{
PONTO DE INTERROGAÇÃO: PSEUDÔNIMO DESCONHECIDO E TEXTO INÉDITO DE MACHADO DE ASSIS ${ }^{1}$
}

\section{FERNANDO BORSATO}

Universidade de São Paulo

São Paulo, São Paulo, Brasil

Resumo: Ao longo de sua vida literária, Machado de Assis utilizou muitas e variadas formas para assinar seus textos. Aqui, incluímos um pseudônimo até então desconhecido no conjunto de assinaturas do escritor. Trata-se de um ponto de interrogação ("?"), sinal com o qual subscreveu um texto esquecido nas folhas do Correio da Tarde e ainda inédito, que publicamos ao final do artigo. Tal atribuição será feita a partir de uma autorreferência contida no conhecido texto "O folhetinista", da série "Aquarelas", assinado com a forma "M-as".

Palavras-chave: Machado de Assis; Autorreferência; Assinatura; Pseudônimo; Folhetinista; Correio da Tarde; O Espelho.

\section{A QUESTION MARK: UNKNOWN PSEUDONYM AND A UNKOWN TEXT BY MACHADO DE ASSIS}

Abstract: Throughout his literary life, Machado de Assis signed his texts in many different ways. Here we add a hitherto unknown pseudonym to the set of signatures he used. It is a question mark ("?"), which the author used to sign a forgotten text in the pages of Correio da Tarde. We have published this unreported text at the end of this article. This attribution is based on the author's reference to himself in the wellknown text "O folhetinista" from the "Aquarelas " series, where " $M$-as" appears in the byline.

Keywords: Machado de Assis; Self-reference; Signature; Pseudonym; Folhetinista, Correio da Tarde; O Espelho.

\footnotetext{
${ }^{1}$ Este artigo resulta de pesquisa de mestrado, em andamento no Programa de Literatura Brasileira da Faculdade de Filosofia, Letras e Ciências Humanas da Universidade de São Paulo, com apoio da FAPESP, a qual propõe estudar, de forma sistemática, as práticas de assinatura de Machado de Assis.
} 
Já é tempo de se começar a compreender a obra de Machado de Assis como um todo coerentemente organizado [...].

Silviano Santiago, "Retórica da verossimilhança"

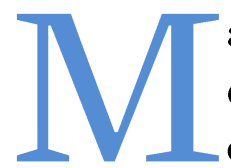

achado de Assis colaborou com $O$ Espelho, periódico de Eleutério de Sousa, entre 4 de setembro de 1859 e 8 de janeiro 1860. Contava o escritor vinte anos de idade e, dentre outras formas de assinatura, utilizava naquelas folhas o pseudônimo "M-as", com o qual subscreveu o texto "A reforma pelo jornal" (ASSIS, 1859b), a série "Revista de teatros" e os textos intitulados "Aquarelas".

Foi no número 9 de $O$ Espelho, de 30 de outubro de 1859, que Machado publicou o texto "Aquarelas - IV. - O folhetinista", no qual, a certa altura, estabelece a assinatura "M-as", com a qual está subscrito, como sendo um pseudônimo. Vejamos:

O folhetim, disse eu em outra parte, e debaixo de outro pseudônimo, o folhetim nasceu do jornal, o folhetinista por consequência do jornalista. Esta íntima afinidade é que desenha as saliências fisionômicas da moderna criação. (ASSIS, 1859a, p. 1-2)

\section{O folhetim, disse eu em outra parte, e debaixo de outro pseudonymo, o folhetim nasceu do jor- nal, o folhetinista por consequencia do jorna- lista. Esta intima afinidade é que desenha as saliencias physionomicas na moderna creação.}

Figura 1: trecho de "Aquarellas - IV - O folhetinista", publicado em O Espelho, 30 de outubro de 1859, p. 1-2.

Após M-as fazer menção ao que dissera "em outra parte" afirmando que o fizera "debaixo de outro pseudônimo", o leitor pode rapidamente acrescentar: outro que não este "M-as". Portanto, M-as fica classificado, por si mesmo, como um pseudônimo, e o texto ao qual se refere, ainda que de forma vaga, recebe, através dessa mesma menção, uma declaração de autoria dada pelo próprio autor, Machado de Assis.

${ }^{2}$ Como, por exemplo, O Espelho, Rio de Janeiro, $\mathrm{n}^{\circ}$ 2, de 11 de setembro de 1859. 


\section{A autorreferência em Machado de Assis}

No trecho de "O folhetinista" que destacamos, como em outros casos posteriores, ocorre um duplo movimento: o de chamar a atenção para um texto anterior e, ao mesmo tempo, dificultar a localização desse texto, omitindo outras informações que seriam necessárias para realizar tal tarefa. É semelhante ao que encontramos em Papéis avulsos, quando, em nota (F), o autor diz, a respeito do conto "Uma visita de Alcebíades": "Este escrito teve um primeiro texto, que reformei totalmente mais tarde, não aproveitando mais do que a ideia. O primeiro foi dado com um pseudônimo e passou despercebido" (ASSIS, 1882, p. 300).

Ora, se o autor não considerou importante citar quais foram o texto e o pseudônimo utilizados, que já haviam passado despercebidos, por que os mencionar? E se, por outro lado, considerou que o "primeiro texto" teria alguma importância, por que omitir o pseudônimo e outros dados para sua localização? Se sabemos que aquele "primeiro texto" fora publicado quase dez anos antes de Papéis avulsos, no Jornal das Famílias de outubro de 1876, sob a assinatura Victor de Paula, não é somente graças à indicação feita em nota naquele livro de contos. Naquele mesmo Papéis avulsos, entretanto, a nota B, referente ao conto "A chinela turca", nos entrega todos os dados necessários: "Este conto foi publicado, pela primeira vez, na Epocha, n. 1, de 14 de novembro de 1875. Trazia o pseudônimo de Manassés, com que assinei outros artigos daquela folha efêmera" (ASSIS, 1882, p. 294).

Foi partindo de uma menção como essas que Wilton Marques, a partir da nota referente ao poema "Maria Duplessis", recolhido em Crisálidas (ASSIS, 1864b), descobriu ter sido aquele poema uma, provavelmente, primeira tradução de Machado de Assis, realizada em 1856 (e não em 1858, conforme consta na nota) e a partir de um texto em prosa, publicado sob outra assinatura, L.a. - a qual Marques atribui a Leonel de Alencar (MARQUES, 2018).

O procedimento que aqui se apresenta, e que seria usado ainda muitas vezes por Machado, é o que podemos chamar, adaptando os conceitos usados por Harold Love (2002), em Attributing Authorship, ${ }^{3}$ de autorreferência; isto é, no interior de um trabalho reconhecidamente seu, o escritor faz referência,

\footnotetext{
${ }^{3}$ Refiro-me aos termos self-reference e self allusion, usados como sinônimos por Harold Love, para casos em que, no interior de um texto, o autor faz alusão ou descrição de suas próprias experiências, dando, assim, indícios de sua autoria (LOVE, 2002, p. 288-289).
} 
completa ou parcialmente, a outro texto de sua autoria empírica, ainda que, eventualmente, seja atribuído ficcionalmente a outrem.

Esse tipo de autorreferência na obra de Machado ocorre em diversos espaços: no interior do texto propriamente dito ou, digamos melhor, principal, como no já citado texto "O folhetinista", ou como em Quincas Borba, onde, no quarto capítulo, se lê "Este Quincas Borba, se acaso me fizeste o favor de ler as Memórias póstumas de Brás Cubas, é aquele mesmo náufrago da existência" (ASSIS, 1891, p. 5); ocorre também nos paratextos, como as notas de Crisálidas (ASSIS, 1864b) e Papéis avulsos (ASSIS, 1882) que também mencionamos; e em zonas já complexas que misturam, ao menos mais explicitamente, ficção e realidade, como nas Advertências de Memorial de Aires ("Quem me leu Esaú e Jacó [...]" [ASSIS, 1908, p. 1]) e de Esaú e Jacó, que aludem aos diários do conselheiro Aires, personagem ficcional.

Foi esse procedimento de autorreferência que permitiu a Galante de Sousa identificar a autoria de Machado na carta, assinada com o asterônimo ***, para o bispo do Rio de Janeiro, publicada no Jornal do Povo (Rio de Janeiro, ano I, $n^{\circ} 3$ ), a partir da autorreferência feita pelo autor em $O$ Futuro (Rio de Janeiro, $1^{\circ}$ de março de 1863), que diz: "Assinavam essa carta umas três estrelas, ocultando o verdadeiro nome do autor, que era eu" (ASSIS, 2009, p. 13). ${ }^{4}$ Permitiu, também a Sousa, acrescentar à lista de pseudônimos de Machado a letra Y e a versão anterior de "Potira", que em Americanas leva a seguinte nota do seu autor: "destinava-o à publicação anônima, o que se verificou nas colunas do Jornal do Commercio em junho e agosto de 1870, tendo por assinatura um simples Y" (ASSIS, 1875, p. 200). Outro exemplo é o item 117 da Bibliografia de Machado de Assis que apresenta outra autorreferência de Machado, conforme nos conta Galante de Sousa (1955, p. 344): "O autor inicia a peça citando um trecho seu, sem dizer, entretanto, de onde. Encontra-se o texto, que constitui tal citação, em REVISTA DE THEATROS (O Espelho, Rio, no 5, 2-10-1859)".

Como dizíamos, o procedimento no texto sobre o folhetinista, publicado em $O$ Espelho (1859), é semelhante a esses outros casos de autorreferência, em que o texto aludido é duplamente indicado e omitido. Mas quais seriam, afinal, essa "outra parte" e "outro pseudônimo" aos quais se refere M-as?

Afirmou-se que a referência seria ao texto publicado no Correio Mercantil, em 10 e 12 de janeiro de 1859, intitulado "O jornal e o livro" que levou a assinatura "Machado de Assis" (ASSIS, 2013, p. 84). Essa afirmação

\footnotetext{
${ }^{4}$ A atribuição de Galante de Sousa (1955, p. 354) se dá em sua Bibliografia, item 145.

${ }^{5}$ Em nota de $n^{\circ} 75$.
} 
não nos parece ajustada. No texto publicado no Correio Mercantil, Machado de Assis trata da relação entre o jornal e o livro e não do folhetim com o jornal, nem do folhetinista com o jornalista. Ademais, o texto foi assinado com o nome literário do escritor e não com um pseudônimo, como afirmava o texto publicado em $O$ Espelho.

Por meio do material disponibilizado pela Hemeroteca Digital da Biblioteca Nacional, conseguimos localizar o texto ao qual se refere M-as e, com ele, as novidades de que trataremos a partir de agora.

\section{"A lanterna de Diógenes": "um livro por publicar"}

Trata-se do primeiro capítulo de um livro intitulado "A lanterna de Diógenes - (Folhetins noturnos: um livro por publicar)", que saiu no ano anterior, quando Machado tinha ainda dezenove anos de idade, no Correio $d a$ Tarde, no dia 22 de outubro de 1858, e que foi assinado com um pseudônimo até então desconhecido: um sinal de pontuação, um ponto de interrogação:

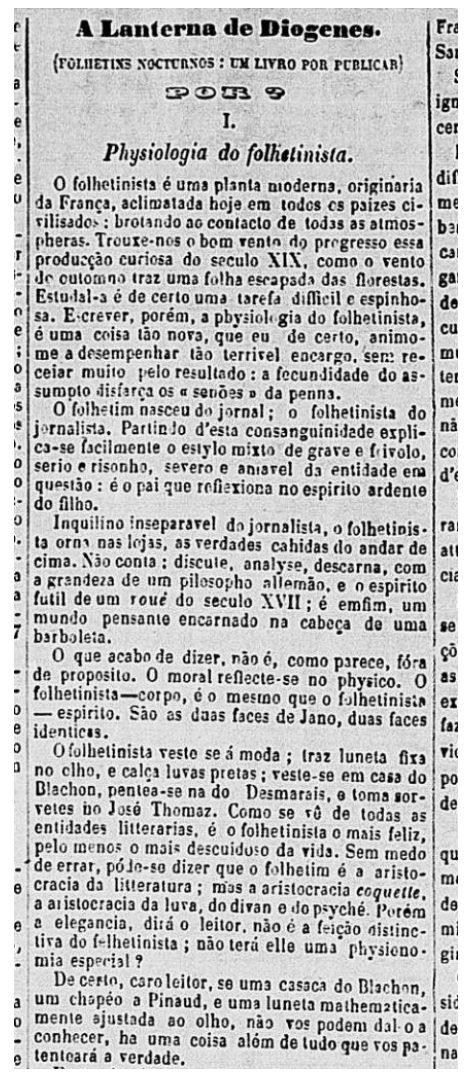

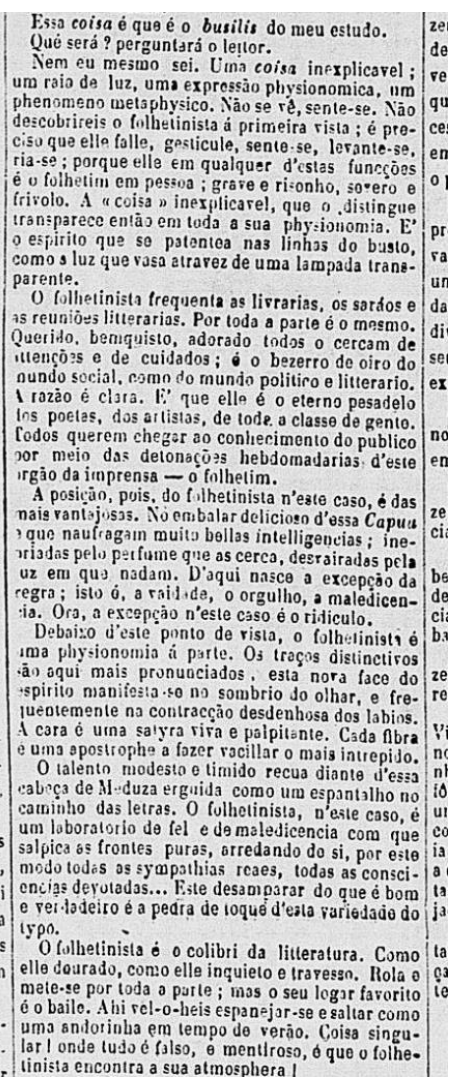

Mas o doloroso no meio de tudo isto, é que o folheiluista sú púle aspirar a um suffragio contempo-
taneo; o $\mathrm{h}$ isisonie da gloria para elle está circums.

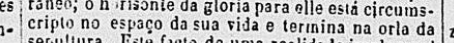
sefultura. Este facto de uma realijada implacare do tumulo nào nasce dos improrisos do jorno alenı nein da Indolencia inebrialte de uma rida orienttal; a reftaxào e of provaçäss producera-n'a e man- et tens n'a. Mas só en Franca ex $\mathbf{s}$ ste a o o paiz enn que rire. nós è quasi um inyitho. Esta planta exatica, transplantada para aqui, perdeu muito da sua origina.

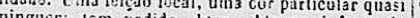
initar, lem podido obter. Alguns a furça de ria du mundo.

Poiz é pena ! Podiam bem occupar uma posicào no muaido litterario sem ferir tâo cruelmeate, e or ha do face o sersocominam.

Figura 2: texto publicado no Correio da Tarde, Rio de Janeiro, ano IV, n. 237, 22 de outubro de 1858, p. 2. 
Através do cotejo do texto "O folhetinista" publicado em O Espelho (OE) com esse primeiro capítulo, intitulado "Fisiologia do folhetinista", publicado no Correio da Tarde (CT), verificamos ser este mesmo o texto ao qual se refere M-as. Vejamos as semelhanças:

Em OE, o já citado trecho:

O folhetim, disse eu em outra parte, e debaixo de outro pseudônimo, o folhetim nasceu do jornal, o folhetinista por consequência do jornalista. (ASSIS, 1959a, p. 1-2)

\section{Em CT:}

O folhetim nasceu do jornal; o folhetinista do jornalista.

Mas, além desses, há outros trechos paralelos, que dispomos na tabela abaixo:

\begin{tabular}{|c|c|c|}
\hline Em O Espelho (1859) & Em Correio da Tarde (1858) & Observações \\
\hline $\begin{array}{l}\text { Uma das plantas europeias } \\
\text { que dificilmente se tem } \\
\text { aclimatado entre nós, é o } \\
\text { folhetinista. } \\
{[\ldots . .]} \\
\text { O folhetinista é originário } \\
\text { da França, onde nasceu, e } \\
\text { onde vive a seu gosto, como } \\
\text { em cama no inverno. De lá } \\
\text { espalhou-se pelo mundo, } \\
\text { ou pelo menos por onde } \\
\text { maiores proporções } \\
\text { tomava o grande veículo do } \\
\text { espírito moderno; falo do } \\
\text { jornal. }\end{array}$ & $\begin{array}{l}\text { O folhetinista é uma planta } \\
\text { moderna, originária da } \\
\text { França, aclimatada hoje em } \\
\text { todos os países civilizados: } \\
\text { brotando ao contato de } \\
\text { todas as atmosferas. } \\
\text { Trouxe-nos o bom vento do } \\
\text { progresso essa produção } \\
\text { curiosa do século XIX, } \\
\text { como o vento do outono } \\
\text { traz uma folha escapada } \\
\text { das florestas. }\end{array}$ & $\begin{array}{l}\text { Embora as estações do } \\
\text { ano tenham se alterado } \\
\text { na passagem de um texto } \\
\text { para o outro, isto é, do } \\
\text { outono para o inverno, a } \\
\text { caracterização do } \\
\text { folhetinista como planta } \\
\text { originária da França } \\
\text { permanece a mesma. }\end{array}$ \\
\hline $\begin{array}{l}\text { O folhetinista, na sociedade } \\
\text { ocupa o lugar do colibri na } \\
\text { esfera vegetal; salta, } \\
\text { esvoaça, brinca, tremula, } \\
\text { paira e espaneja-se sobre } \\
\text { todos os caules suculentos, } \\
\text { sobre todas as seivas }\end{array}$ & $\begin{array}{l}\text { O folhetinista é o colibri da } \\
\text { literatura. Como ele } \\
\text { dourado, como ele inquieto } \\
\text { e travesso. Rola e mete-se } \\
\text { por toda a parte; mas o seu } \\
\text { lugar favorito é o baile. }\end{array}$ & $\begin{array}{l}\text { Temos a referência ao } \\
\text { colibri nos dois textos. }\end{array}$ \\
\hline
\end{tabular}




\begin{tabular}{|c|c|c|}
\hline $\begin{array}{l}\text { vigorosas. Todo mundo lhe } \\
\text { pertence; até mesmo a } \\
\text { política. } \\
\text { [...] é fácil encontrá-lo no } \\
\text { primeiro teatro ou baile } \\
\text { aparecido. }\end{array}$ & & \\
\hline $\begin{array}{l}\text { Todos o amam, todos o } \\
\text { admiram, porque todos têm } \\
\text { interesse em estar de bem } \\
\text { com esse arauto amável que } \\
\text { levanta nas lojas do jornal, } \\
\text { a sua aclamação } \\
\text { hebdomadária. }\end{array}$ & $\begin{array}{l}\text { O folhetinista frequenta as } \\
\text { livrarias, os saraus e as } \\
\text { reuniões literárias. Por } \\
\text { toda a parte é o mesmo. } \\
\text { Querido, benquisto, } \\
\text { adorado todos o cercam de } \\
\text { menções e de cuidados; é o } \\
\text { bezerro de oiro do mundo } \\
\text { social, como do mundo } \\
\text { político e literário. A razão } \\
\text { é clara. É que ele é o eterno } \\
\text { pesadelo dos poetas, dos } \\
\text { artistas, de toda a classe de } \\
\text { gente. Todos querem } \\
\text { chegar ao conhecimento } \\
\text { público por meio das } \\
\text { detonações hebdomadárias } \\
\text { d'este órgão da imprensa - } \\
\text { o folhetim. }\end{array}$ & $\begin{array}{l}\text { O folhetinista é amado } \\
\text { por todos. }\end{array}$ \\
\hline $\begin{array}{l}\text { O folhetinista é a fusão } \\
\text { admirável do útil e do fútil, } \\
\text { o parto curioso e singular } \\
\text { do sério, consorciado com o } \\
\text { frívolo. Estes dois } \\
\text { elementos arregados como } \\
\text { polos, heterogêneos como } \\
\text { água e fogo, casam-se } \\
\text { perfeitamente } \\
\text { organização do novo } \\
\text { aminal [sic]. }\end{array}$ & $\begin{array}{l}\text { O folhetim nasceu do } \\
\text { jornal: o folhetinista do } \\
\text { jornalista. Partindo desta } \\
\text { consanguinidade explica- } \\
\text { se facilmente o estilo misto } \\
\text { de grave e frívolo, sério e } \\
\text { risonho, severo e amável da } \\
\text { entidade em questão: é o } \\
\text { pai que reflexiona o } \\
\text { espírito ardente do filho. } \\
\text { [...] Nã descobrireis } \\
\text { Não } \\
\text { folhetinista à primeira } \\
\text { vista; é preciso que ele fale, } \\
\text { gesticule, sente-se, levante- }\end{array}$ & $\begin{array}{l}\text { O folhetinista encerra } \\
\text { opostos. }\end{array}$ \\
\hline
\end{tabular}




\begin{tabular}{|c|c|c|}
\hline & $\begin{array}{l}\text { se, ria-se; porque ele em } \\
\text { qualquer destas funções é o } \\
\text { folhetim em pessoa; grave e } \\
\text { risonho, severo e frívolo. }\end{array}$ & \\
\hline $\begin{array}{l}\text { Alguns vão até Paris } \\
\text { estudar a parte fisiológica } \\
\text { dos colegas de lá; é inútil } \\
\text { dizer que degeneram no } \\
\text { físico como no moral. }\end{array}$ & $\begin{array}{l}\text { Inquilino inseparável do } \\
\text { jornalista, o folhetinista } \\
\text { orna nas lojas, as verdades } \\
\text { caídas do andar de cima. } \\
\text { Não conta: discute, analise } \\
\text { [sic], descarna, com a } \\
\text { grandeza de um filósofo } \\
\text { alemão, e o espírito fútil de } \\
\text { um roué do século XVII; é } \\
\text { enfim, um mundo pensante } \\
\text { na cabeça de uma } \\
\text { borboleta. } \\
\text { O que acabo de dizer, não é, } \\
\text { como parece, fora de } \\
\text { propósito. O moral reflete- } \\
\text { se no físico. O folhetinista- } \\
\text { corpo, é o mesmo que o } \\
\text { folhetinista-espírito. São as } \\
\text { duas faces de Jano, duas } \\
\text { faces idênticas. }\end{array}$ & $\begin{array}{l}\text { O folhetinista é a junção e } \\
\text { degeneração do físico e do } \\
\text { moral. }\end{array}$ \\
\hline $\begin{array}{l}\text { Na apreciação do } \\
\text { folhetinista pelo lado local, } \\
\text { temo talvez cair em } \\
\text { desagrado negando a } \\
\text { afirmativa. Confesso } \\
\text { apenas excepções. Em } \\
\text { geral o folhetinista aqui é } \\
\text { todo parisiense; torce-se a } \\
\text { um estilo estranho, e } \\
\text { esquece-se nas suas } \\
\text { divagações sobre o } \\
\text { boulevard e Café Tortoni de } \\
\text { que estão sobre mac-adam } \\
\text { lamacento e com uma } \\
\text { grossa tenda lírica no meio } \\
\text { de um deserto. }\end{array}$ & $\begin{array}{l}\text { O folhetinista varia } \\
\text { segundo o país que vive. } \\
\text { Mas só em França existe a } \\
\text { raça genuína. Entre nós é } \\
\text { quase um mito. } \\
\text { Esta planta exótica, } \\
\text { transplantada para aqui, } \\
\text { perdeu muito da sua } \\
\text { originalidade. Uma feição } \\
\text { local, uma cor particular } \\
\text { quase ninguém tem podido } \\
\text { obter. Alguns à força de } \\
\text { imitar, ou antes, copiar, os } \\
\text { colegas de além-mar } \\
\text { caíram na caricatura, e na }\end{array}$ & $\begin{array}{l}\text { Por fim, falta ao } \\
\text { folhetinista "mais cor } \\
\text { local". }\end{array}$ \\
\hline
\end{tabular}




\begin{tabular}{|c|c|c|}
\hline $\begin{array}{l}{[\ldots . .]} \\
\text { Força é dizê-lo; a cor } \\
\text { nacional, em raríssimas } \\
\text { exceções tem tomado o } \\
\text { folhetinista entre nós. } \\
\text { Escrever folhetim e ficar } \\
\text { brasileiro é na verdade } \\
\text { difícil. } \\
\text { Entretanto como todas as } \\
\text { dificuldades se aplanam, } \\
\text { ele podia bem tomar mais } \\
\text { cor local, mais feição } \\
\text { americana. Faria assim } \\
\text { menos mal à } \\
\text { independência do espírito } \\
\text { nacional, tão preso a essas } \\
\text { imitações, a esses } \\
\text { arremedos, a esse suicídio } \\
\text { de originalidade e } \\
\text { iniciativa. }\end{array}$ & $\begin{array}{l}\text { caricatura mais irrisória do } \\
\text { mundo. } \\
\text { Pois é pena! Podiam bem } \\
\text { ocupar uma posição no } \\
\text { mundo literário sem ferir } \\
\text { tão cruelmente em, e tão de } \\
\text { face o senso comum. }\end{array}$ & \\
\hline
\end{tabular}

Acreditamos que, com o cotejo realizado até aqui, não restam dúvidas de que o texto ao qual se refere M-as no texto de 1859, em O Espelho, é o que fora publicado em 1858 no Correio da Tarde. ${ }^{6}$ De modo geral, embora decorrido o período de um ano e alguns dias entre as publicações, e a mudança de pseudônimo, percebem-se muitas coincidências nas ideias desenvolvidas em torno do folhetinista, como vimos.

Vemos, também, que a procura por uma "cor local", que havia aparecido no texto "O passado, o presente e o futuro da literatura - Ao Sr. Dr. Manuel Antônio de Almeida", publicado em A Marmota com a assinatura Machado d'Assis em abril de 1858, ou seja, alguns meses antes de "A lanterna de Diógenes", e que seria assunto na célebre "Notícia da atual literatura brasileira - instinto de nacionalidade" (ASSIS, 1873, p. 107), fora também preocupação do folhetinista, portanto, no texto publicado no Correio da Tarde, naquilo que

${ }^{6}$ Para o texto integral v. Anexo ao final.

7 "Gonzaga, um dos mais líricos poetas da língua portuguesa, pintava cenas da Arcádia, na frase de Garret, em vez de dar uma cor local às suas liras, em vez de dar-lhes um cunho puramente nacional. Daqui uma grande perda: a literatura escravizava-se, em vez de criar um estilo seu, de modo a poder mais tarde influir no equilíbrio literário da América." (ASSIS, 1858) 
chamou, então, de "uma feição local, uma cor particular [que] quase ninguém tem podido obter".

Interessado em questões fundamentais em torno dos modos de atribuição de autoria e em fornecer critérios confiáveis para atribuição de autoria individual de textos, Harold Love (2002) nos conta que a disciplina de atribuição distingue, convencionalmente, evidências internas de evidências externas. De modo geral, a evidência interna é aquela que parte de dentro da própria obra, enquanto a evidência externa é obtida a partir do mundo social no qual a obra foi criada, propagada e lida.

Desse modo, são incluídos como elementos das evidências externas: (1) as atribuições contemporâneas; ou contidas em documentos que sejam capazes de transmitir informações sobre as circunstâncias de composição do texto - especialmente diários, correspondências, registro de editores e de processos judiciais; (2) evidência biográfica, que pode incluir informação sobre as alianças do autor reputado, paradeiro, datas, vínculos pessoais e afiliações políticas e religiosas; (3) a história das atribuições anteriores da obra e as circunstâncias em que foram feitas.

As evidências internas podem ser: (1) evidência estilística; (2) auto-alusão e auto-apresentação dentro da obra; e (3) evidências a partir da similaridade de temas, ideias, crenças e concepções de gênero manifestadas na obra (LOVE, 2002, p. 51). Love (2002, p. 88) usa self-reference, self allusion e selfpresentation como sinônimos para aludir aos casos em que, no interior de uma obra, o autor empírico faz alusão ou descrição de suas próprias experiências, dando, assim, indícios de sua autoria. Reservamos, como o fizemos anteriormente, autorreferência para os casos em que o autor faz referência a outro texto de sua autoria.

Para exemplificar as evidências internas que se podem tirar a partir de temas e ideias, Love (2002, p. 83) menciona a análise realizada por R. W. Chambers em seu ensaio "Shakespeare and the play of More", no qual argumenta, a partir do que chama de "combinações", sequências de tópicos no desenvolvimento de um argumento. Também o relacionamento de ideias similares, segundo Love (2002, p. 86), pode ser usado para uma identificação positiva, embora a força de uma atribuição resida em ser ela feita a partir de mais ou menos combinações de diferentes tipos de evidência.

O cotejo que realizamos até aqui nos fornece evidências internas de diversos tipos: a autorreferência ("disse eu em outra parte, e debaixo de outro pseudônimo"), a similaridade de ideias e de estilo e a "combinação" de tópicos para o desenvolvimento de um argumento. 
O que poderíamos, talvez, classificar como evidência externa, concernente ao contexto da publicação, é o fato de que Machado de Assis já havia colaborado no Correio da Tarde, embora, até onde se sabe, com apenas um poema. Dois meses antes de "Fisiologia do folhetinista", em 6 de agosto de 1858, Machado publicara o poema "A Elvira"8 com a assinatura "J. M. Machado de Assis" e datado de julho do mesmo ano. Essa era, como dissemos, a única colaboração de Machado conhecida até agora para aquele jornal. ${ }^{9}$

Não houve continuação dos "folhetins noturnos", que seriam publicados em livro, ao que parece, com o título "A lanterna de Diógenes", nem outro texto publicado sob aquele pseudônimo no Correio da Tarde. O título é uma metáfora, que teve sua explicação publicada mais ou menos contemporaneamente ao texto, em 1873, no Jornal das Famílias, na seção "Variedades - alusões históricas". Transcrevemos abaixo:

\section{A LANTERNA DE DIÓGENES}

Quando Diógenes viveu, já os atenienses estavam na sua época de decadência; e enquanto Demóstenes, célebre orador, procurava estimulá-los com a sua arrebatadora eloquência pela recordação das glórias passadas, ele estigmatizava-os com o ridículo. Uma vez foi encontrado ao meio-dia com uma lanterna acesa; e como lhe perguntassem a causa d'essa extravagância, respondeu que procurava um homem.

É a esse fato que frequentemente aludem os escritores modernos na expressão supra. (ANÔNIMO, 1877, p.368-9)

Machado usou a metáfora da lanterna de Diógenes em diversos momentos ao longo de sua obra. Em 14 de janeiro de 1862, na série de crônicas "Comentários da Semana" que publicava no Diário do Rio de Janeiro, com a assinatura M. A., dizia:

Os atenienses riram-se muito um dia ao ver que Diógenes, um doudo que vivia em um tonel, saíra com uma lanterna na mão, à cata de um homem. Era para rir. E aquele povo não deu o cavaco, porque via no ato do velho

\footnotetext{
${ }^{8}$ Magalhães Júnior foi o responsável pela recuperação do poema e é ele mesmo quem adverte: "['A Elvira',] que até aqui escapou a todos os pesquisadores e que não deve ser confundido com poesia de igual título que constou do volume Falenas" (MAGALHÃES JÚNIOR, 2008, p. 80-81).

${ }^{9}$ É verdade que há também uma transcrição de um poema de Machado, publicado na seção "Notícias de Artigos Diversos", no dia 10 de fevereiro de 1860. A notícia, transcrição do Jornal do Commercio do mesmo dia, trata da litografia de Carlos Linde, em que há o poema supracitado de Machado. Teve o poema várias edições e desencontros, como foi discutido em (MIRANDA; CAMPOS, 2018).
} 
filósofo um arroto de vaidade com visos de desdém pelos contemporâneos.

Rir-se-ão os Fluminenses se me virem atravessar (perdoa-me, ó Diógenes), não as ruas da cidade, mas os dias da semana, com uma lanterna na mão à cata de notícias? (ASSIS, 1862, p. 01)

Dois anos depois, na série "Ao acaso", também publicada no Diário do Rio de Janeiro e com a mesma assinatura, voltou a usar a metáfora na crônica de 11 de setembro de 1864:

[...] dizia o cínico Diógenes, no dia em que se lembrou de clamar em plena rua de Atenas:

- Ó homens! ó homens!

E como os atenienses que passavam se reuniam em torno do filósofo, e lhe perguntavam o que queria, ele lhes respondeu com a mordacidade do costume:

- Não é a vocês que eu chamo; eu chamo os homens. (ASSIS, 1864a, p. 1)

Está presente também na fala de Estevão, personagem do conto "A mulher de preto", originalmente publicado no Jornal das Famílias (Rio de Janeiro, abril e maio de 1868, p. 114-122 e 133-151, respectivamente), e recolhido em Contos Fluminenses (1870):

Entrando em casa Estevão dizia consigo:

- Onde está a misantropia daquele homem? As maneiras de misantropo são mais rudes do que as dele; salvo se ele, mais feliz do que Diógenes, achou em mim o homem que procurava. (ASSIS, 1977a, p. 105)

Também em 1877, na série "História de quinze dias", assinada com o pseudônimo de Manassés, na Illustração Brasileira (Rio de Janeiro, n. 24, 15 de junho de 1877): "Achei um homem; vou apagar a lanterna. [...] Diógenes, filósofo sem préstimo nem fortuna [...]. Eu, sim, achei um homem" (ASSIS, 2015, p. 337). Em 26 de julho de 1896, na série anônima "A Semana", publicada na Gazeta de Notícias, o escritor novamente usaria a metáfora: "Apaguem a lanterna de Diógenes: achei um homem" (ASSIS, 1896, p. 01).

Por fim, a expressão aparece, também, no capítulo CLX de Quincas Borba:

Sofia cuidou que ainda podia sair; estava inquieta por ver, por andar, por sacudir aquele torpor, e esperou que o sol varresse a chuva e tomasse conta do céu e da terra; mas o grande astro percebeu que a intenção dela era constituí-lo lanterna de Diógenes, e disse ao raio úmido: "Volta, volta 
ao meu seio, raio casto e virtuoso; não vás conduzi-la onde o seu desejo a quer levar." (ASSIS, 1977c, p. 303)

Sendo que a versão publicada em livro sofreu a supressão do complemento da metáfora, presente na versão anterior do texto, publicada no periódico A Estação: "[...] o grande astro percebeu que a intenção dela era constituí-lo lanterna de Diógenes, para achar um homem, e disse [...]" (ASSIS, 1977d, p. 204).

A metáfora, portanto, como demonstramos, foi utilizada por Machado ao longo de toda a sua vida literária e de tal forma recorrente que, poderíamos dizer, quase constitui o seu uso como mais uma evidência interna, de semelhança e combinações de ideias.

A busca por um homem é o sentido que se ajusta à metáfora presente no título do texto publicado no Correio da Tarde, que busca a definição de um tipo específico, o folhetinista. Tal relação mostra certa coerência com o projeto crítico-literário de Machado em relação ao que afirma no texto "O passado, o presente o futuro da literatura", publicado alguns meses antes em A Marmota:

A sociedade, Deus louvado! É uma mina a explorar, é um mundo caprichoso, onde o talento pode descobrir, copiar, analisar, uma aluvião de tipos e caracteres de todas as categorias. Estudem-na: eis o que aconselhamos às vocações da época! (ASSIS, 1858, $\mathrm{n}^{\circ}$ 945, p. 02)

A metáfora que aparece nos títulos do "livro por publicar" e capítulo publicados no Correio da Tarde sugerem que Machado tinha a intenção de fazer uma espécie de álbum dos tipos sociais, que, se não foi adiante com o título "A lanterna de Diógenes", podemos dizer que teve certo desenvolvimento em $O$ Espelho, sob outra assinatura (M-as) na série "Aquarelas", que não só inclui o tipo do folhetinista como retoma algumas ideias do texto "fisiologia do folhetinista". As "Aquarelas" duraram um pouco mais. Foram quatro capítulos publicados, cada um destinado a descrever um tipo social: os fanqueiros literários, o parasita, o empregado público aposentado e, por fim e, desta vez, por último, o folhetinista. ${ }^{10}$

Encontrar esse texto no Correio da Tarde, subscrito com um enigmático ponto de interrogação, assinatura até então desconhecida, mostra que mesmo depois de decorridos os, recém-completados, 180 anos do nascimento de Machado de Assis, e de trabalhos extensivos e monumentais como os de

${ }^{10}$ As "Aquarelas" saíram em $O$ Espelho, Rio de Janeiro, em 11 e 18 de setembro e em 9, 16 e 30 de outubro de 1859. 
Galante de Sousa (1955), Magalhães Júnior (1956; 2008), Michel Massa (2009), Lúcia Miguel Pereira (1988 [1953]) e outros, há ainda lacunas existentes nas biografias e bibliografias do escritor. As muitas perguntas que surgem a partir da descoberta parecem ainda determinadas a permanecerem incógnitas, bem ao gosto de Machado de Assis, já pela assinatura com a qual subscreveu o texto que as suscitaram, o próprio ponto de interrogação!

\section{$* * *$ \\ ANEXO: \\ A lanterna de Diógenes ${ }^{11}$ \\ (FOLHETINS NOTURNOS: UM LIVRO POR PUBLICAR) POR ?}

I.

Fisiologia do folhetinista

O folhetinista é uma planta moderna, originária da França, aclimatada hoje em todos os países civilizados: brotando ao contato de todas as atmosferas. Trouxe-nos o bom vento do progresso essa produção curiosa do século XIX, como o vento do outono traz uma folha escapada das florestas. Estudá-la é de certo uma tarefa difícil e espinhosa. Escrever, porém, a fisiologia do folhetinista, é uma coisa tão nova que eu de certo, animo-me a desempenhar tão terrível encargo, sem recear muito pelo resultado: a fecundidade do assunto disfarça os "senões" da pena.

O folhetim nasceu do jornal; o folhetinista do jornalista. Partindo desta consanguinidade explica-se facilmente o estilo misto de grave e frívolo, sério e risonho, severo e amável da entidade em questão: é o pai que reflexiona no espírito ardente do filho.

Inquilino inseparável do jornalista, o folhetinista orna nas lojas, as verdades caídas do andar de cima. Não conta: discute, analise [sic], descarna, com a grandeza de um filósofo alemão, e o espírito fútil de um roué do século XVII; é enfim, um mundo pensante encarnado na cabeça de uma borboleta.

${ }^{11}$ A ortografia dessa e de outras transcrições foi, por nós, atualizada. De tudo o mais nada se alterou. 
O que acabo de dizer, não é, como parece, fora de propósito. O moral reflete-se no físico. O folhetinista - corpo, é o mesmo que o folhetinista espírito. São as duas faces de Jano, duas faces idênticas.

$\mathrm{O}$ folhetinista veste-se à moda; traz luneta fixa no olho, e calça luvas pretas; veste-se em casa do Blachon, ${ }^{12}$ penteia-se na do Desmarais, ${ }^{13}$ e toma sorvetes no José Thomaz. ${ }^{14}$ Como se vê de todas as entidades literárias, é o folhetinista o mais feliz, pelo menos o mais descuidoso da vida. Sem medo de errar, pode-se dizer que o folhetim é a aristocracia coquette, a aristocracia da luva, do divã e do psiquê. Porém a elegância, dirá o leitor, não é a feição distintiva do folhetinista; não terá ele uma fisionomia especial?

De certo, caro leitor, se uma casaca do Blachon, um chapéu a Pinaud, e uma luneta matematicamente ajustada ao olho, não vos podem dá-lo a conhecer, há uma coisa além de tudo que vos patenteará a verdade.

Essa coisa é que é o busílis do meu estudo.

Que será? Perguntará o leitor.

Nem eu mesmo sei. Uma coisa inexplicável; um raio de luz, uma expressão fisionômica, um fenômeno metafísico. Não se vê, sente-se. Não descobrireis o folhetinista à primeira vista; é preciso que ele fale, gesticule, sente-se, levante-se, ria-se; porque ele em qualquer destas funções é o folhetim em pessoa; grave e risonho, severo e frívolo. A "coisa" inexplicável, que o distingue transparece então em toda a sua fisionomia. É o espírito que se patenteia nas linhas do busto, como a luz que vasa através de uma lâmpada transparente.

O folhetinista frequenta as livrarias, os saraus e as reuniões literárias. Por toda a parte é o mesmo. Querido, benquisto, adorado todos o cercam de menções e de cuidados; é o bezerro de oiro do mundo social, como do mundo político e literário. A razão é clara. É que ele é o eterno pesadelo dos poetas, dos artistas, de toda a classe de gente. Todos querem chegar ao conhecimento do público por meio das detonações hebdomadárias deste órgão da imprensa - o folhetim.

\footnotetext{
12 Provavelmente Antônio Blachon, francês, sepultado em 20 de abril de 1857 (cf. Correio da Tarde, Rio de Janeiro, 20 de abril de 1857, p. 3), considerado o melhor alfaiate de coletes masculinos, que atendia na rua do Ouvidor (cf. O Jornal das Senhoras, Rio de Janeiro, Tomo II, 01 de agosto de 1852 e Marmota na Corte: Jornal de Modas e Variedades, Rio de Janeiro, $\mathrm{n}^{\circ} 201,14$ de outubro de 1851).

13 Provavelmente "Alexandre \& Francisco Desmarais, Cabelereiros da Casa Imperial, rua do Ouvidor, 86", onde se vendia objetos de luxo e de toucador (cf. Almanak Administrativo, Mercantil e Industrial da Corte e do Rio de Janeiro para o ano de 1850, Rio de Janeiro, p. 383).

${ }^{14}$ A loja de doces e sorvetes de José Thomaz era um dos locais de divertimento da sociedade fluminense daquela época. (cf. Novo Correio das Modas: Novellas, Poesias, Viagens, Recordações Historicas, Anecdotas e Charadas, Rio de Janeiro, segundo semestre de 1854, p. 143).
} 
A posição, pois, do folhetinista neste caso, é das mais vantajosas. No embalar delicioso dessa Capua é que naufragam muito belas inteligências; inepropriadas [sic] pelo perfume que as cerca, desvairadas pela [1]uz em que nadam. Daqui nasce a exceção da regra; isto é, a vaidade, o orgulho, a maledicência. Ora, a exceção neste caso é o ridículo.

Debaixo deste ponto de vista, o folhetinista é uma fisionomia à parte. Os traços distintivos são aqui mais pronunciados, esta nova face do espírito manifesta-se no sombrio do olhar, e frequentemente na contratação desdenhosa dos lábios. A cara é uma sátira viva e palpitante. Cada fibra é uma apóstrofe a fazer vacilar o mais intrépido.

O talento modesto e tímido recua diante dessa cabeça de Medusa erguida como um espanto no caminho das letras. O folhetinista, neste caso, é um laboratório de fel e de maledicência com que salpica as frontes puras, arredando de si por este modo todas as simpatias reais, todas as consciências devotadas... Este desemparar do que é bom e verdadeiro é a pedra de toque d'esta variedade do tipo.

O folhetinista é o colibri da literatura. Como ele dourado, como ele inquieto e travesso. Rola e mete-se por toda a parte; mas o seu lugar favorito é o baile. Aí vê-lo-eis espanejar-se e saltar como uma andorinha em tempo de verão. Coisa singular! Onde tudo é falso, e mentiroso, é que o folhetinista encontra a sua atmosfera!

Mas o doloroso no meio de tudo isto, é que o folhetinista só pode aspirar a um sufrágio contemporâneo; o horizonte da glória para ele está circunscrito no espaço da sua vida e termina na orla da sepultura. Este fato de uma realidade implacável está contido na ordem das coisas. A reputação além do túmulo não nasce dos improvisos do jornalismo, nem da indolência inebriante de uma vida oriental; a reflexão e as provações produzem-na e mentem-na.

O folhetinista varia segundo o país em que vive. Mas só em França existe a raça genuína. Entre nós é quase um mito. Esta planta exótica, transplantada para aqui, perdeu muito da sua originalidade. Uma feição local, uma cor particular quase ninguém tem podido obter. Alguns à força de imitar, ou antes, copiar, os colegas de além-mar caíram na caricatura, e na caricatura mais irrisória do mundo.

Pois é pena! Podiam bem ocupar uma posição no mundo literário sem ferir tão cruelmente, e tão de face o senso comum.

?

(Correio da Tarde, Rio de Janeiro, ano IV, n. 237, 22 de outubro de 1858, p. 2) 


\section{Referências}

ANÔNIMO. A lanterna de Diógenes. Jornal das Famílias, Rio de Janeiro, ano XV, n. 12, dez. 1877, p. 368-369.

ASSIS, Machado de. O passado, o presente e o futuro da literatura. A Marmota, Rio de Janeiro, n. 941, 09 abr. 1858, p. 01-2; n. 945, 23 abr. 1858, p. 01-2. . Aquarellas - IV - O folhetinista. O Espelho, Rio de Janeiro, 30 out. 1859a, p. 12.

A reforma pelo jornal. O Espelho, Rio de Janeiro, n. 8, 31 out. 1859b, p. 01-2. . Comentarios da semana. Diário do Rio de Janeiro, Rio de Janeiro, Ano XLII, n. 14, 14 jan. 1862, p. 1-2.

. Ao acaso (chronica da semana). Diário do Rio de Janeiro, Rio de Janeiro, Ano XLIV, n. 250, 11 set. 1864a, p. 1.

. Chrysalidas - poesias de Machado de Assis - com um prefácio do Dr. Caetano Filgueiras. Rio de Janeiro: Livraria de B. L. Garnier, 1864b.

.Noticia da Actual Literatura Brazileira - Instincto de Nacionalidade. O Novo Mundo, 24 de março de 1873, pp. 107-8.

Americanas. Rio de Janeiro: B. L. Garnier Livreiro-editor do Instituto Histórico, 1875.

. Papeis avulsos, Rio de Janeiro: Lombaerts \& C., 1882.

- Quincas Borba. Rio de Janeiro: B. L. Garnier, 1891.

. A Semana. Gazeta de Notícias, Rio de Janeiro, Ano XXII, n. 207, 26 jul. 1896,

p. 01.

. Memorial de Aires. Rio de Janeiro: H. Garnier, livreiro-editor, 1908.

. Contos fluminenses. (Edições críticas das obras de Machado de Assis. Vol. 15).

Brasília: Civilização Brasileira; INL, 1977a.

. Esaú e Jacob. (Edições críticas das obras de Machado de Assis. Vol. 15).

Brasília: Civilização Brasileira; INL, $1977 b$.

- Quincas Borba. (Edições críticas das obras de Machado de Assis. Vol. 15).

Brasília: Civilização Brasileira; INL, 1977c.

. Quincas Borba (Apêndice). (Edições críticas das obras de Machado de Assis.

Vol. 15). Brasília: Civilização Brasileira; INL, 1977d.

. Correspondência de Machado de Assis. Coordenação e orientação Sergio Paulo

Rouanet. Coleção Afrânio Peixoto. Rio de Janeiro: Academia Brasileira de Letras, 2009. v. 1.

; Machado de Assis: crítica literária e textos diversos. Organização de Maria

Sílvia Azevedo, Adriana Dusilek, Daniela Mantarro Callipo. São Paulo: Editora

UNESP, 2013.

. 15 de junho de 1877. Obra Completa. São Paulo: Editora Nova Aguilar, 2015. v. IV (Crônicas).

LOVE, Harold. Attributing Authorship: An Introduction. Cambridge: Cambridge University Press, 2002. 
MAGALHÃES JÚNIOR, Raimundo. Contos esparsos - organização e prefácio de R. Magalhães Junior. Rio de Janeiro: Editora Civilização Brasileira, 1956. . Machado de Assis: vida e obra. Volume 1: Aprendizado. Rio de Janeiro: Editora Record, 2008.

MASSA, Jean-Michel. A juventude de Machado de Assis 1839-1870: ensaio de biografia intelectual. São Paulo: Editora UNESP, 2009.

MARQUES, Wilton. Machado de Assis e "Maria Duplessis": a talvez primeira tradução. Machado de Assis em Linha - Revista Eletrônica de Estudos Machadianos, São Paulo, v. 11, n. 25, p. 33-63, dez. 2018. Disponível em: $<$ http://machadodeassis.fflch.usp.br/>. Acesso em: 06 jul. 2019. doi: 10.1590/1983-6821201811253.

MIRANDA, José Américo; CAMPOS, Alex Sander Luiz. Edição dos versos alexandrinos de Machado de Assis: poemas anteriores a Crisálidas (1864) e não incluídos nesse livro. Machadiana Eletrônica, Vitória, v. 1, n. 1, p. 65-73, jan.-jun. 2018. Disponível em: <http://www.periodicos.ufes.br/machadiana/article/ view/17698/13334>. Acesso em: 08 jul. 2019.

PEREIRA, Lúcia Miguel. Machado de Assis: estudo crítico e biográfico. 6. ed. rev. Belo Horizonte; Itatiaia; São Paulo: Editora Universidade de São Paulo, 1988 [1953]. SANTIAGO, Silviano. Retórica da verossimilhança. In: Uma leitura nos trópicos. 2. ed. Rio de Janeiro: Rocco, 2000. p. 27-46.

SOUSA, José Galante de. Bibliografia de Machado de Assis. Rio de Janeiro: Ministério da educação e cultura; Instituto Nacional do Livro, 1955.

FERNADO BORSATO é bacharel em Letras (Português e Inglês) pela Universidade de São Paulo. Atualmente, é aluno de mestrado do Programa de Pós-graduação em Literatura Brasileira, na mesma universidade, onde desenvolve o projeto "As assinaturas de Machado de Assis: estudo sobre as figurações da autoria", com apoio da Fapesp; é assistente editorial da Machado de Assis em linha - revista eletrônica de estudos machadianos. https://orcid.org/0000-0002-9487-4619. E-mail: fernando.borsato.santos@usp.br

Recebido: 07.10.2019 Aprovado: 30.10.2019 